\title{
Access to farmland: A systems change perspective
}

\author{
Kathryn Z. Ruhf* \\ Land For Good, Inc.
}

\begin{abstract}
Submitted May 17, 2013 / Revised July 17, July 18, and August 6, 2013 / Accepted August 6, 2013 /
Published online December 9, 2013

Citation: Ruhf, K. Z. (2013). Access to farmland: A systems change perspective. Journal of Agriculture, Food Systems, and Community Development, 4(1), 51-60. http://dx.doi.org/10.5304/jafscd.2013.041.006

Copyright (C) 2013 by New Leaf Associates, Inc.
\end{abstract}

\begin{abstract}
While the topic of farmers' access to farmland is not a new issue, contemporary conditions have made it an even greater challenge than in the past. In this reflective essay I suggest that the farmland access challenge in the U.S. means thinking outside the box of ingrained cultural values, past historical arrangements, and current conditions. Using my organization, Land For Good, I argue that persistent challenges to farmland access will be addressed best through dialogue and innovation around how farms and farmland can optimally be accessed, held, and passed on. Land For Good, a New England-based not-for-profit organization, posits a systems change framework for farmland access, tenure, and transfer. This essay explores solutions in a broad context and addresses how farm seekers, landowners, service providers, communities, and policymakers all play key roles.
\end{abstract}

\section{Keywords}

access to land, farm leasing, farm linking, farm seekers, farm succession, farm transfer, farmland access, farmland owners, farmland tenure

\footnotetext{
* Kathryn Z. Ruhf, Executive Director, Land For Good, Inc.; P.O. Box 625; Keene, New Hampshire 03431 USA; +1-603-357-1600; kathy@landforgood.org
}

\section{The Farmland Access Challenge}

While the topic of farmers' access to farmland is not a new issue, contemporary conditions have made it an even greater challenge than in the past. Access to affordable agricultural land has posed problems for farmers throughout our nation's history (Parsons et al., 2010). "How farm land is acquired, held in ownership, operated, or rented has always been a matter of national interest, for just and fair conditions of tenure are recognized as essential to our national welfare" (Clark, 1944, p. 145). This quote from 1944 bears as much relevance to the farmland access challenge today as it did nearly 70 years ago. This "matter of national interest" is not just within the agricultural community; farmland access and tenure have economic, cultural, aesthetic, and quality-of-life impacts on entire communities.

The purpose of this essay is to use the experiences of Land For Good (LFG), a New England nonprofit specializing in farm access, tenure, and succession, to highlight and discuss current challenges and opportunities surrounding these issues. In my experience, current demographic, economic, and cultural trends have further compounded the persistent challenges facing farmers when it comes to gaining access to and secure tenure on farmland in the U.S. In this paper, I draw from my experi- 
ence to make the case for a broad, systems approach to addressing farmland access. I address the various stakeholder sectors that play a necessary part in addressing the obstacles: beginning and other farm seekers, farming and nonfarming landowners, service providers, communities, and policy-makers. I share LFG's perspective, experiences, and challenges and argue for new thinking and dialogue.

Twenty-six years ago, I joined the staff of the New England Small Farm Institute (NESFI). At the time NESFI was negotiating a lease for 400 acres (162 hectares) of public land which it proposed in turn to sublease to start-up farmers. It took nearly the 17 years I was at NESFI to finalize that lease. During that time, I started one of the first farm link programs in the country, helped found the National Farm Transition Network, ${ }^{1}$ and co-authored two guidebooks on farmland access and tenure (Higby, Ruhf, \& Woloschuk, 2004; Ruhf, 1999). With partners, NESFI delivered workshops on farm succession throughout New England. During that time I also served for six years on the U.S. Department of Agriculture (USDA) Advisory Committee on Beginning Farmers and Ranchers, where access to land, capital, and training were enduring themes.

These experiences gave me a good grounding in the issues and practicalities around land access and tenure locally as well as nationally. When I joined Land For Good ${ }^{2}$ nine years ago (now serving as executive director), it was with the intent to build an organization devoted to better understanding, educating about, and improving how farmers acquire, hold, and pass on farms. In the near-decade since then, I've seen farmland access become a much higher profile topic for local food advocacy and conservation groups as well as for the USDA. I've also deepened my appreciation for the complexity of the topic.

Between 1982 and 2007, more than 23 million acres of farmland were lost to development (American Farmland Trust, n.d.) despite efforts to staunch the loss of agricultural land to other uses. By one estimate, 70 percent of the remaining

1 http://www.farmtransition.org

2 http://www.landforgood.org farmland will change hands over the next two decades (Kohl \& White, 2001). Our aging farmer demographic reflects not only a slowed rate of exit by older farmers, but a decline in the rate of farm entry, with less than 2 percent of farmland owners under the age of 35 (USDA, NASS, 1999). One consequence is that farm ownership is increasingly concentrated among older farmers. We observe how established farmers compete for additional available acres with two consequences: a growing trend toward part-owner-operator (own some land and rent some land) and less opportunity for new farmers to acquire land through purchase or rent. Along with availability, the cost of land is a huge obstacle. In just eight years (2000-2008), U.S. farmland values more than doubled (USDA, NASS, 2009), making "the entrance bar to farming... higher and higher” (Bell, p. 52).

From my perspective, cultural values specifically those favoring ownership of land undergird these challenges. The culture of property ownership is deeply engrained in our society. The Jeffersonian agrarian ideal of independent farmers owning their own land retains its potency. Despite high land prices, the reality that approximately onethird of principle operators rent some or all of the land they farm, and findings that farmers starting out without landownership debt (i.e., those on rented land) are more likely to succeed (Dodson, 1996), land ownership still prevails as a goal for many farmers.

The word "tenure" derives from the Latin word tenir, meaning to hold. Our present day landholding challenge is to foster what in 1909 Liberty Hyde Bailey called the "equitable partition of land [which is] the necessary basis of all self-sustaining agriculture" (Bailey, 1909, p. 70). Bailey's "equitable partition of land" may take the form of ownership of land or the form of recognized rights to use land and related natural and built resources for farming. Tenancy has long been recommended as a first step for beginning farmers (Bell, 2004). At the same time, tenancy in the U.S. has been controversial. This controversy stems in part from regional histories, particularly in the South with the abysmal story of sharecropping. As pointed out in 1936, however, "The evil is not in renting land; it is in the traditions and usages which have grown up about 
the share tenant group in the old South" (Embree, 1936, p. 149). To me, cultural attitudes about farmland tenure are integral to this discussion. How farmers, landowners, and lenders feel about tenancy shape current reality as well as what might be possible.

From my perspective addressing farmland access means not simply putting more farmers on land using established mechanisms, although this is a worthy and necessary objective. Improving farmland access now and into the future means thinking of land access beyond ingrained cultural values, past historical arrangements, and current conditions. I believe that persistent challenges to farmland access will be addressed best through dialogue and innovation around how farms and farmland can optimally be accessed, held, and passed on.

The underlying assumption that guides LFG is that society will benefit from enabling types of farmland tenure that are more appropriate and more beneficial for more farmers while also meeting the needs of landowners and the land itself. That is our goal in addressing the farmland access challenge.

LFG's basic framework is to make farms and farmland:

- Available (enough land in a suitable location that is accessible and findable);

- Affordable (for purchase or rent; not the same as cheaper land);

- Appropriate (for farming and related uses, security, housing, infrastructure); and

- Equitable (division of rights and responsibilities between the landowner and the operator, equity).

Appropriate approaches to farmland tenure may take multiple forms, depending on farmer goals and values, local conditions, cultural context, economics, stage and type of farming, and more. These approaches will reflect a range of core values that in my opinion currently are not well enough lifted up into the discussion. Values are part of the land access challenge, as much as price, policy, and preference. Do we want to strive for the Jeffersonian ideal of "widely dispersed ownership of land by family farmers" (Higby et al., 2004) in the face of increasing concentration of farmland ownership, public policies that reinforce land ownership, and the reality that about 40 percent of U.S. farmland is rented?

What are the values embedded in business models that emphasize control of an asset over ownership, and do they apply to agriculture? What are the values that undergird the landowner/land user dynamic? In our framework, farmland access and tenure are shaped by broader value systems as well. For us, these include:

- Environmental stewardship values at the farm, community, regional, and global levels;

- Cultural values associated with place, tradition, relationships, and agrarian legacy;

- Social values regarding equity, opportunity, and diversity; and

- Economic values regarding ownership and control of business assets.

\section{A Systems Response}

My 26 years in farm and food systems work have shaped me as a systems thinker. To me, given the rapid pace of change and the complexity of the issue, analyzing and transforming farmland access and tenure require systems thinking. In my systems approach I look at the problem from multiple angles, contexts and levels - and try to understand the connections among them. I consider the various stakeholders and forces (economic, demographic, cultural, policy, etc.) that influence and are influenced by how farmers acquire, hold, and transfer farm properties. And I try to understand these systems of farmland access, tenure, and transfer in a larger context; that is, how they function within and interact with other important systems from a specific farm enterprise system, to regional or national agri-food systems, and broad socioeconomic or cultural systems. At LFG we seek to consider how farmland access shapes - and is shaped by — these other systems.

Given the high cultural value placed on property ownership in the U.S., applying systems thinking to land access and its larger contexts is not simply an academic exercise. At LFG our under- 
standing of and assumptions about these dynamic systems are fundamental to how we define the problem, as well as how we design our strategies and monitor our progress. LFG is a not-for-profit organization that works in the six-state New England region (Connecticut, Maine, Massachusetts, New Hampshire, Rhode Island, and Vermont). We specialize in farmland access, tenure, and transfer. Employing a systems approach, LFG believes that how land is acquired cannot be separated from how it is held over time and how it is transferred. In this framework, the key stakeholders include farm seekers, established farmers, landowners, service providers, communities, and policymakers (figure 1). Each of these stakeholder groups has an integral part to play in improving access to - and appropriately secure tenure on - productive farmland over generations. This is not a revolutionary framework in itself. Our contribution is to emphasize the interplay among these stakeholders at the program and policy levels.

\section{Who Are Farm Seekers?}

Farm seekers are new and beginning farmers who want to access land for the first time or scale up their operations, as well as establish farmers who want to expand or relocate their farms. Access to land is a particular obstacle for new and beginning farmers. A survey of new farmers by the National Young Farmers Coalition identified access to land as a top challenge (Shute, 2011). The 2013 annual survey by the American Farm Bureau Federation substantiated this finding: "Securing adequate land... was the top challenge identified in the latest survey of participants in the American Farm Bureau Federation's Young Farmers \& Ranchers program" (American Farm Bureau Federation, 2013, para. 1). The traditional pattern of young farmers starting out through intrafamily succession accounted for less than half of farmland acquisitions in the 1980s (Rogers \& Wunderlich, 1993), and one study found that less than a quarter of farm acquisitions were through inheritance (Duffy \& Smith, 2009). The most common method of acquiring land for beginning as well as established farmers is from a non-relative (USDA, 2013).

Beginning farmers in the $21^{\text {st }}$ century are a heterogeneous group. Using the USDA definition, a beginning farmer is an individual or entity who has never operated a farm or ranch, or who has operated a farm or ranch for not more than 10 consecutive years. Further distinctions are useful. Using the typology developed by the Growing New Farmers Project (New England Small Farm Institute, 2004), people who plan to farm but are not yet farming ("prospective" farmers) have different ideas and needs about land than start-up farmers (those in their first three years of farming), and than those who are reconfiguring their operation, expanding, and/or relocating in years four through 10 of farming. Within the beginning farmer demographic, socially disadvantaged, minority, women, immigrant, refugee, and veteran farmers have unique challenges in accessing land to farm (Parsons et al., 2010). Established farmers are not exempt from land access and tenure challenges such as competition for land, escalating rental rates, financing issues, conservation investments and other improvements, and navigating landlords and farm programs.

\section{Figure 1. Components of the Land Access "System"}

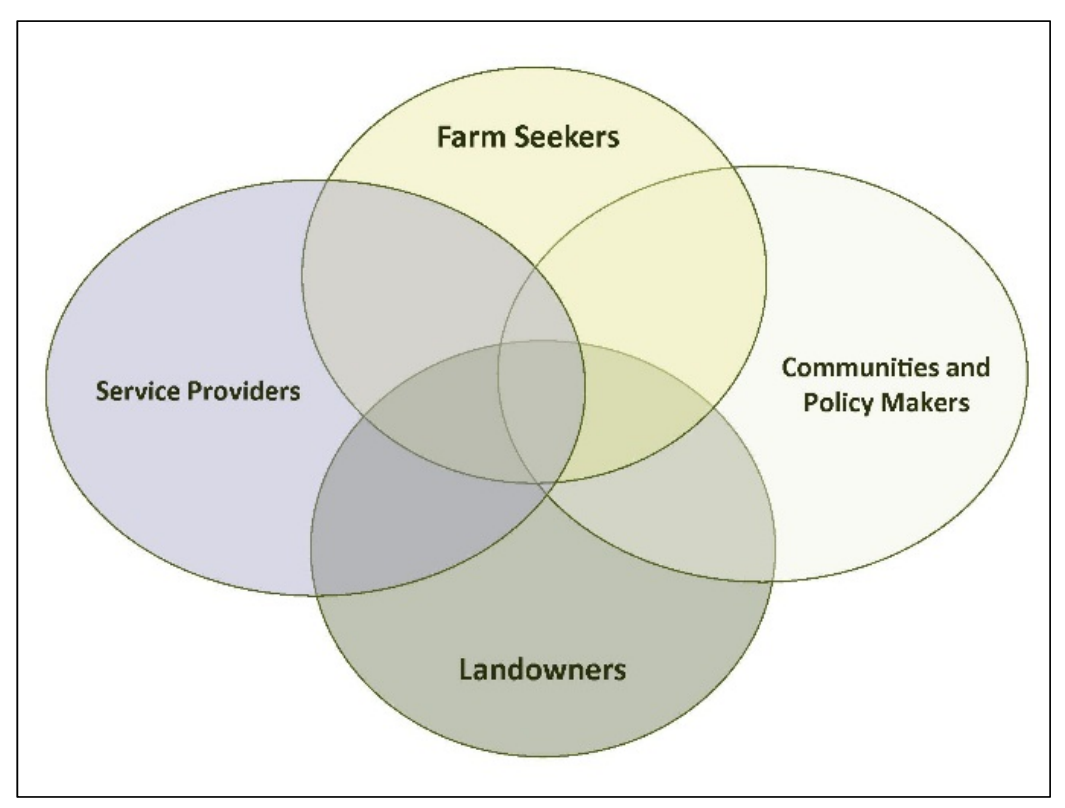




\section{Who Are Landowners?}

For this discussion, a landowner is any person(s) or any entity who owns land with agricultural uses or potential. As stressed above, access to land is as much about who owns the land as who hopes to access and use it. And, as with farm seekers, the landowning demographic is heterogeneous. From a systems perspective, we have to understand and work with all types of owners to improve access to farmland.

We (and others) divide farmland owners into two major categories: those who farm and those who don't. In our experience, farming landowners typically are established farmers who own at least some of the land they farm. They may rent out some of the land they own to other farmers. For this discussion, the most significant cohort within the farming landowner category is older operators. "If older farmers can't easily exit, their land can't become available to entering farmers" (Parsons et al., 2010, p. 10). Much discussion exists (for example, Parsons et al., 2010) about the aging farmer demographic, and in particular around the pressing challenges related to farm exit. Farmers are living longer and postponing retirement; some say they will "never retire" (Baker, Duffy, \& Lamberti, 2000). In one study, 82 percent of farmers did not have an exit strategy nor did they know how to develop one (Spafford, 2006).

We studied factors that influence farmers' reluctance to engage in timely succession planning. In market research commissioned by Land For Good, the most often reported reasons include not enough time to plan, and being "not ready yet" (Aschkenase, Babbitt, \& Wilbur, 2010). Beneath this often are emotions such as anxiety, fear, and sadness, as well as family dynamics and perceptions of daunting legal and financial complexities. Current and future farm viability, income during retirement, and treatment of farming and nonfarming heirs are crucial considerations. Increasingly, one of the biggest obstacles is not having an identified successor. In one Iowa study, less than one-third of retiring farmers had identified a successor (Baker et al., 2000).

The other main category of farmland owners in our typology is nonfarming landowners, which we further break into private and public entities. In the private category are retired farmers; widows of farmers (such as 19 percent of Iowa farmland owners, for example (Duffy and Smith, 2009)) and other heirs of farmers; other private landowners (e.g., estate properties, second homes); organizations and institutions (e.g., religious, educational, conservation, intentional communities); and, increasingly, investors, including individuals and investment funds. Public landowners include municipal, county, state, and federal lands, examples of whose holdings include protected open space and parkland.

Historically referred to as absentee landlords, we see a trend of private landowners living further away from their properties (Parsons et al., 2010). On the other hand, we see a new demographic emerging: resident nonfarming landowners who live on or next to their farmed (or farmable) property. In the U.S., 88 percent of farm landlords are not farmers (USDA, NASS, 1999). The land they own represents 42 percent of the nation's farmland (Hoppe, 2006). Nationally, as farm landlords are more separated from their land by geography and generation, they become less involved and engaged with their rented properties and with the communities where the land is located (Parsons et al., 2010). I have observed that until very recently nonfarming landowners were seriously neglected as part of the land access picture.

\section{The Role of Service Providers}

From my perspective, engaging seekers and landowners is not enough. If our goal is to improve land access and tenure for the nation's farmers, we have to engage service providers, communities, and policy-makers as part of the system we seek to change. We need more involved and skilled service providers to guide and assist farm seekers as well as landowners. We need involved and supportive civic leaders, neighbors, and community groups. And we need public policies that remove obstacles to land access, foster secure land tenure, support timely and rewarding transitions, and promote a stewardship ethic among farmland owners, whether or not they farm.

From our work at LFG and with colleagues in our region and nationally, we confirm that a wide range of service providers is needed to address 
farmland access, tenure, and transfer. Ideally, we would have fully developed networks of programs, services, and advisors to support farm seekers, farmers, and landowners through all stages. Such networks would consist of various agricultural specialists and also attorneys, land use planners, mediators, affordable housing experts, lenders, real estate agents, and more. From my vantage point, adequate networks do not exist in any region of the country.

In the past decade there has been a significant growth in programs for beginning farmers. This is good and important. Most readers know of beginning farmer training programs, incubators, networks, and business planning courses, for example. Within USDA, the Beginning Farmer and Rancher Development Program (BFRDP) has spurred and supported dozens of projects and services targeted to new farmers. Most beginning farmer education programs focus on production and business training. On the land side, farm link programs (which link farm seekers with retiring farmers as well as nonfarming landowners) are springing up.

Farm link programs have been around since the mid-1990s. I've been involved with and observed them for 20 years. From my perspective, their accomplishments and strengths are notable but uneven in attempts to connect farm seekers with landowners for purchase or rental transactions. Successful "matches" are few, and, in my opinion, the focus on "matches" as the expected outcome overshadows the various other critical functions that such programs do or could perform. LFG's Land Access Project (LAP), which ran from 2010 to 2013 and was funded by BFRDP, analyzed farm link programs in New England and elsewhere. One outcome of this analysis was to distinguish these functions that are often conflated or confused. Linking programs differ in whether and how they execute the functions. LAP differentiated three distinct functions:

1. Listing: creating and maintaining a list of farm properties;

2. Linking: sorting or screening for potential seeker-owner compatibility and exchanging contact information; and
3. Matching: facilitating specific, customized transactions.

One conclusion of our investigation was that these functions are necessary but not sufficient alone to foster successful tenure arrangements. Farmland seekers and owners need easy, efficient methods to find one another. We need to do much better in this regard. But they also need preparation — as well as sustained support — to engage successfully in a tenure or transfer transaction. LFG stresses "readiness" by both seekers and landowners. Improving readiness involves services related to but different from linking, requiring different skills, expertise, and resources.

To improve readiness, seeker and landowner education is essential. One of LFG's core premises is that too many seekers (especially beginning farmers) are inadequately informed about land tenure options, farm financing, and lease agreements, for example. As a result, they embark down the "linking" path with a high risk of failure.

On the other side of the land "match" equation, nonfarming landowners need information and often a lot of support to realistically and successfully engage with a farming tenant or transferee. In our experience, this is as true with public and organizational landowners and managers as it is with private landowners. Some landowners we encounter are naïve and unrealistic; others can be overly involved and undermining. Service providers can help with educational materials, along with individualized and often labor-intensive technical assistance. For example, at LFG, field agents may spend 50 or more hours over several months working with landowners to assess properties, set goals, and guide farmer recruitment. At a minimum, providers need enough information on this topic to guide their audiences toward the proper resources and subject matter experts and advisors. To this end, LFG and American Farmland Trust have embarked on a USDA-funded program ${ }^{3}$ to train 80 Extension educators and other providers in basics about land access and transfer.

One of the challenges I see for the serviceprovider community is around capacity and focus.

3 http://www.farmland.org/farmlandadvisors 
With the above-mentioned project we are building knowledge and skills for a wide range of providers so they can better assist seekers, farm families, and landowners on these issues. The goal is to make them more able to provide solid, basic information, share resources, and direct their clients to more expertise. They are not — nor should they be expected to be - subject-matter experts. We also need more specialists with expertise in such areas as leasing and agricultural conservation easements.

We deal with this challenge within our own organization. Our field agents have varying degrees of subject-matter expertise, but we promote ourselves to our clients as "coaches," coordinators or facilitators of their own discovery and planning processes, rather than experts. We are still refining this role and how to set expectations and boundaries. From the experience I bring to LFG, I believe that informed, personalized, sustained support for seekers, exiting farm families, and landowners is absolutely essential. While it is necessary, it is not sufficient; hence the necessity for a coordinated service network.

Regarding land stewardship, popular thinking holds that tenant farmers do not care for the land as much as owner-operators (Parsons et al., 2010). It is understandable from a business perspective that farmers with annual agreements might be inclined to manage (or mine) the land for shortterm gain with little regard for stewarding the land over the long term. The research reveals a more nuanced reality (Parsons et al., 2010, pp. 49-50). For example, cultural factors often play a large role in how farmers manage land, whether they own the land or farm it as tenants. Farmer and landowner attitudes and relationships are as important as the land tenure arrangement. To me, this opens another opportunity and need for service providers to help support and inform both sides toward shared stewardship objectives. As mentioned above, landowners have not been adequately served. LFG has produced several guides and tools for landowners, but our main struggle continues to be in finding and engaging them. We've had some success with workshops at the local level. We've had less success attracting them to farm link websites.
Transitioning farm families have their own unique set of needs that in my view are not addressed well enough by existing service-provider networks. Farm succession planning requires a number of specialists. Advisors with specialties in applicable laws and regulations, taxes, financial planning, farm viability, long-term health care, land use, farmland preservation, entity formation, farm management, retirement planning, communications, and estate planning have a role to play. In my experience, a constellation of experts is not enough. They need to work as a coordinated team for the benefit of the client family.

Succession planning requires sustained effort, support, and coordination (Ruhf, 2013). After attending a day-long workshop on farm estate and succession planning, most farmers reported to us they did not know what to do next. They say they believe in succession planning, and report that paying for it is not an obstacle (Aschkenase, Babbitt, \& Wilbur, 2011); rather it is the task complexity and "soft issues" that are perceived as daunting. These soft issues revolve around values, goals, communications, interpersonal relations, and the emotions that underpin them.

LFG's response to this obstacle is to play the coordination and coaching role. We are still working out how best to do this. We are learning how to "keep the ball rolling" when families are resistant or overwhelmed. We are smoothing out how we bring in and coordinate advisors.

We depend on these advisors to be sufficiently skilled and conversant about their area of expertise as well as knowledgeable about the bigger picture to make connections and explore different perspectives and methods outside their realm. For example, an estate planning attorney or retirement planner who lacks sufficient understanding about the role that an agricultural easement can play is less likely to include easements as a planning tool. LFG conducted a day-long peer- and cross-training for attorneys, land use planners, accountants, conservation agents, and others for exactly this purpose. To help exiting families find the support they need, the Farm Transfer Network of New England's website ${ }^{4}$ lists succession planning advisors by

${ }^{4}$ http://www.farmtransfernewengland.net 
specialty and state. Yet in our experience, this is not good enough. We are exploring the effectiveness of small support groups, incentives, and lower or no fees to see whether this will enable us to assist more farmers with succession planning.

\section{The Role of Communities and Policy-makers}

Both farmers and landowners function in a community context. From our systems perspective, the community consists of the immediate physical and social-economic surroundings of the farm and farmer, as well as the larger environment and social, economic, and political systems that interact with farmland owners and users. Civic leaders, conservationists, planners, consumers, "foodies," historic preservationists, economic developers, educators, neighbors, real estate agents, and agency decision-makers, and increasingly local food and farming advocacy groups and philanthropies, are part of the system that influences - and can influence - how farmland is acquired, held, and transferred. To us at LFG, these are fruitful and also at times challenging sectors to engage.

Ironically, it is hard to grab the attention of these sectors given all the "noise" and traffic around food system issues these days. Further, policy solutions - and the role of public policy — are not obvious.

How towns regard farming will influence whether and how they offer public land for agriculture, invite new farmers in, and help older farmers in transition. One Massachusetts town contracted with LFG to revitalize a significant agricultural neighborhood. We identified additional available farmland, brought in conservation partners, and worked directly with exiting farm families identified in the assessment phase. The New Entry Sustainable Farming Project (Massachusetts) uses GIS to identify potential farmland and then reaches out to specific landowners. At the regional level, the Metropolitan Area Planning Council (Massachusetts) collaborated with LFG and others to promote farming (including land availability, succession, and municipal farmland leasing) in a project spanning 13 eastern Massachusetts towns.

The recent surge in interest in local and regional food systems is an opportunity to engage a broad range of stakeholders, including an extensive network of farming advocacy groups, in farmland access issues. American Farmland Trust's "It's Not Farmland without Farmers" catch phrase captures the connection between food security and keeping farmers on productive land. That connection needs to be strengthened. LFG needs to do a better job in conveying our sense of urgency about and relevance of land access, and in making the connections among, for example, land access and food security, and beginning farmers and community resilience. I think the potential is great. Messages about farming opportunity, legacy, and stewardship can resonate with citizens and new partners who are already energized around farmland conservation, food security, local food and economic systems, community character and quality of life, and environmental stewardship at all scales.

Federal programs can help to foster a systems approach to land access. For example, the Beginning Farmer and Rancher Development Program, a USDA competitive grant program, lists farm succession planning among the topics eligible for funding. The Conservation Reserve Program incentivizes beginning farmers onto CRP land. In March 2013 I attended a two-day "Transitions in Agriculture" meeting hosted by USDA. At the meeting Secretary of Agriculture Vilsack pointed out "how difficult it is to enter farming if [farmers] don't inherit farms" (T. Vilsack, remarks at meeting, March 20, 2013). The discussion among USDA and Extension professionals, land-grant researchers, lenders, and NGO representatives focused on issues related to both farm entry and exit. Participants posed questions: is the owneroperator tenure model tenable? Is the paradigm shifting? Should it?

The questions raised by others at this meeting were a validation of my own exploration. Policymakers, land-access advocates, communities, and service providers must engage in new dialogue about farmland tenure in the U.S. As pointed out in a comprehensive 2010 research report, there is no overarching U.S. policy framework for farmland tenure (Parsons et al., 2010). How should we reconcile the historic and contemporary cultural bias toward owning land with recent trends away from it? How should we consider the realities of farm ownership against practices of outsourcing 
assets that are typical in other business sectors? De facto federal policy has encouraged beginning farmers to purchase farms by offering seductive subsidized loan programs. At the same time, farm advisors and research suggest that for many beginning farmers, renting makes more business sense. Interestingly, this parallels recent trends in home ownership, and for some of the same reasons.

Advocates for nontraditional approaches such as long-term and ground leases need to converse with advocates who hold justifiable fears of perpetual tenancy. Thorny issues such as equitybuilding by tenants, farmland investors, affordable farm housing, and stewardship on rented land must be tackled. The surge in domestic farmland investment should be seen as both alarming and a potential opportunity to foster more values-based alternatives to global land grabbing. Models for lease-to-own, multiple operators on larger properties, shared equity, cooperative tenure, and landlord roles in shared risk need to be explored. Increasing interest on the part of philanthropies needs to be harnessed. Regional and cultural differences add rich dimensions to the discussion.

We don't have solid answers on these perplexing themes or clear policy solutions. Public policy agendas to address land access, tenure, and transfer are informed by research as well as by on-theground experiences of practitioners. Groups such as the International Farm Transition Network and various beginning farmer networks contribute. The research report from the national Farmland Access, Succession, Transfer and Stewardship Project (Parsons et al., 2010) offers dozens of recommendations for policy, programming, and research. LFG's Land Access Project produced a report with innovative policy recommendations (Wagner \& Ruhf, 2013) and another that looked at various farmland investment models with suggestions for values-based approaches (Ruhf \& Wagner, 2013).

\section{Conclusion}

If we seek a more resilient, diverse, and sustainable food and farm system, improved farmland access and tenure must be part of the solution. Within the conversation about land access, my experience tells me that candor about the values implicit in access and tenure models is essential, along with openness to new methods as well as traditional ones to achieve our goals. LFG is continually learning and evolving to meet ongoing and emerging challenges in land access. We are pleased to be a part of the conversation.

\section{References}

American Farm Bureau Federation. (2013). Adequate land ranks as top concern of young farmers. The Voice of Agriculture. Retrieved from http://www.fb.org/ index.php?action $=$ newsroom.news \&year $=2013 \&$ file $=\mathrm{nr} 0307 . \mathrm{html}$

American Farmland Trust. (n.d.). Farmland by the numbers: The National Resources Inventory. Retrieved 11/23/13 from http://www. farmland. org/programs/protection/American-FarmlandTrust-Farmland-Protection-Farmland-by-thenumbers.asp

Aschkenase, T., Babbitt, A., \& Wilbur, J. (2011). Exiting farmer survey results [Unpublished report]. Keene, New Hampshire: Land For Good. Report is available upon request.

Bailey, L. H. (1909). Cyclopedia of American agriculture. New York: Macmillan.

Baker, J. R., Duffy, M. D., \& Lamberti, A. (2000). Farm succession in Iowa. Ames, Iowa: Beginning Farmer Center, Iowa State University Extension. Retrieved from http://www.csrees.usda.gov/nea/economics/ fsll/publications/iowa.pdf

Bell, M. M. (2004). Farming for us all: Practical agriculture and the cultivation of sustainability. University Park, Pennsylvania: Pennsylvania State University Press.

Clark, N. (1944). Improving farm tenure in the Midwest: Problems and recommended policies [Bulletin \#502]. Urbana, Illinois: University of Illinois Agricultural Experiment Station. Retrieved from http://hdl.handle.net/2142/3388

Dodson, C. (1996). Is more credit the best way to assist beginning low-equity farmers? [Agriculture Information Bulletin No. 724-04]. Washington, D.C.: U.S. Department of Agriculture, Economic Research Service. Retrieved from http://www.ers.usda.gov/

Duffy, M., \& Smith, D. (2009). Farmland ownership and tenure in Iowa, 2007. Staff General Research Reports 13013. Ames, Iowa: Iowa State University, University of Extension. Retrieved from http://www.leopold.iastate.edu/pubs-andpapers/2008-11-farmland-ownership 
Embree, E. R. (1936). Southern farm tenancy, the way out of its evils. Survey Graphic, 25(3), 149-153.

Higby, A. M., Ruhf, K. Z., \& Woloschuk, A. (2004). Holding ground: A guide to Northeast farmland tenure and stewardship. Belchertown, Massachusetts: New England Small Farm Institute. Available from http://www.smallfarm.org/main/bookstore/ publications/

Hoppe, R. (2006). Land ownership and farm structure. In K. Wiebe \& N. Gollehon (Eds.), Agricultural Resources and Environmental Indicators, 2006 Edition [Economic Information Bulletin No. 16] (pp. 1623). Washington, D.C.: U.S. Department of Agriculture. Retrieved from http://www.ers.usda. gov/publications/eib-economic-informationbulletin/eib16.aspx\#.UorV2ieFOua

Kohl, D., \& White, A. (2001). The challenge of family business transition. Horizons, 13(5), 1-4. Retrieved from http://www.reap.vt.edu/publications/ horizons/hor13-5.pdf

New England Small Farm Institute. (n.d.). Growing New Farmers Project. http://www.smallfarm.org/main/ special projects/growing new farmers/

Parsons, R., Ruhf, K., Stevenson, G. W., Baker, J., Bell, M., Epley, E.,... Keller, J. (2010). Research report and recommendations from the FarmL ASTS Project.

Retrieved from http://www.uvm.edu/farmlasts/ FarmLASTSResearchReport.pdf

Rogers, C., \& Wunderlich, G. (1993). Acquiring farmland in the United States [Agriculture Information Bulletin No. 682]. Washington, D.C.: U.S. Department of Agriculture, Economic Research Service. Retrieved from http://naldc.nal. usda.gov/download/CAT93511135/PDF

Ruhf, K. (1999). Farmland protection and transfer in New England. Belchertown, Massachusetts: New England Small Farm Institute.
Ruhf, K. (Ed.). (2013). A team approach to farm transfer planning assistance. Keene, New Hampshire: Land For Good. Retrieved from http://www.landforgood.org/pdfs/LFG Team ApproachHbook $\% 20$ FINAL.pdf

Ruhf, K., \& Wagner, R. (2013). Farmland investors: An exploration for New England and beyond. Keene, New Hampshire: Land For Good. Retrieved from http://www.landforgood.org

Shute, L. L. (2011). Building a future with farmers: Challenges faced by young, American farmers and a national strategy to belp them succeed. Tivoli, New York: National Young Farmers Coalition. Retrieved from http://www.youngfarmers.org/

Spafford, K. (2006). Legacy by design: Succession planning for agribusiness owners. Columbia, Maryland: Marketplace Books.

U.S. Department of Agriculture. (2013). Beginning farmers and ranchers at a glance: 2013 edition [Economic Brief No. 22]. Washington, D.C.: Author. Retrieved from http://ers.usda.gov/media/988138/eb-22.pdf

U.S. Department of Agriculture, National Agricultural Statistics Service. (1999). Census of Agriculture: 1999 Agricultural economics and land ownership survey. Retrieved from http://www.agcensus.usda.gov/ Publications/1997/Agricultural Economics and Land Ownership/

U.S. Department of Agriculture, National Agricultural Statistics Service. (2009). Agricultural land values and cash rents: Final estimates 2004-2008 [Statistical Bulletin No. 1017]. Washington, D.C.: Author.

Wagner, R., \& Ruhf, K. (2013). Farmland access and tenure innovations. Keene, New Hampshire: Land For Good. Retrieved from http://www.landforgood.org 